\title{
Proteolytic Pattern, Antigenicity, and Serum Immunoglobulin E Binding of $\beta$-Lactoglobulin Hydrolysates Obtained by Pepsin and High-Pressure Treatments
}

\author{
R. Chicón, ${ }^{*}$ R. López-Fandiño, ${ }^{*}$ E. Alonso,† and J. Belloque ${ }^{\star 1}$ \\ *Instituto de Fermentaciones Industriales, Consejo Superior de Investigaciónes Científicas, Madrid, Spain \\ †Hospital General Universitario Gregorio Marañón, Madrid, Spain
}

\section{ABSTRACT}

This study evaluates the use of high pressure to enhance pepsin hydrolysis of $\beta$-lactoglobulin $(\beta$-LG). The protein was subjected to high pressure before and during the proteolytic process. Analysis of remnant $\beta$-LG, identification of the peptides produced, and evaluation of antigenicity (binding to commercial antibodies) and binding to IgE of allergic patients' sera were conducted in the hydrolysates. The results showed that the application of high pressure before the enzyme treatment slightly improved the proteolytic process but did not reduce the antigenicity or IgE binding of the hydrolysates. The application of high pressure during the enzymatic treatment enhanced the production of large intermediate fragments that were further proteolysed to smaller fragments as proteolysis proceeded for longer periods. At $400 \mathrm{MPa}$, all the intact protein was removed in minutes, simultaneously decreasing its antigenicity and serum IgE binding properties. However, for considerable reduction of the antigenicity and IgE binding of $\beta$-LG, extending the incubation time with the enzyme was needed to reduce the amount of potentially allergenic intermediate peptides. Changes of $\beta$-LG under pressure at acidic $\mathrm{pH}$ are discussed.

Key words: milk whey protein, allergen, high pressure, proteolysis

\section{INTRODUCTION}

Cow's milk allergy is the most common allergy in early childhood. In most cases, it is an IgE-mediated reaction against cow's milk proteins, with gb-LG being one of the major sensitizing agents (Wal, 2001). To prevent allergic symptoms, hypoallergenic formulas are widely used. These formulas are basically protein hydrolysates, frequently manufactured with milk whey

Received August 31, 2007.

Accepted November 8, 2007.

${ }^{1}$ Corresponding author: belloque@ifi.csic.es proteins, which contain a high amount of $\beta$-LG. To efficiently remove the allergenic epitopes, extensive hydrolysis of the protein and ultrafiltration is used. Improving the proteolysis process is of interest to the manufacturing industry to achieve an optimal extent of hydrolysis with respect to allergenic properties, palatability, and nutritional and functional properties (Høst and Halken, 2004).

$\beta$-Lactoglobulin is very resistant to enzyme digestion, particularly to pepsin, a phenomenon attributed to its unique structural stability at acid $\mathrm{pH}$ (Reddy et al., 1988; Dalgalarrondo et al., 1995). At $\mathrm{pH}$ values around 2 , optimum for pepsin activity, $\beta$-LG is dissociated into monomers (Townend et al., 1960), but its folding is similar to neutral pH (Uhrinova et al., 2000; Ragona et al., 2003). The structure of $\beta$-LG is basically a $\beta$ barrel where most hydrophobic amino acids, targets for pepsin, point inward and are not easily accessible to the enzyme. Different means have been used to improve $\beta$-LG digestibility by pepsin, such as chemical modification of the protein (Chobert et al., 1995), addition of denaturing agents to the proteolysis medium (Dalgalarrondo et al., 1995; Guo et al., 1995) and physical treatments, such as heating (Guo et al., 1995; Iametti et al., 2002) or high pressure (Dufour et al., 1995, Stapelfeldt et al., 1996; Peñas et al., 2006).

High-pressure-treated $\beta$-LG is more susceptible to enzyme hydrolysis than the native protein (Maynard et al., 1998; Knudsen et al., 2002). In particular, if the enzyme reaction is performed under high pressure, a significant increase in the proteolysis rate is achieved with several enzymes (Dufour et al., 1995; Stapelfeldt et al., 1996; Maynard et al., 1998; Bonomi et al., 2003; Chicón et al., 2006a,b). This has been attributed to the effect of high pressure on the protein conformation, which favors unfolding, giving rise to regions more exposed to the enzyme action (Dufour et al., 1995; Bonomi et al., 2003; Belloque et al., 2007). However, under high pressure, $\beta$-LG is proteolysed by pepsin at acid $\mathrm{pH}$ with more difficulty than by other proteases at neutral $\mathrm{pH}$ (Dufour et al., 1995; Stapelfeldt et al., 1996; Peñas et 
al., 2006). This is due to the nature of $\beta$-LG, which structure becomes more flexible as the pressure increases but requires higher pressures to unfold at $\mathrm{pH}$ 2.5 than at $\mathrm{pH} 6.8$ and, upon decompression, refolds faster at acid than at neutral $\mathrm{pH}$ (Belloque et al., 2007). The hydrolysates obtained by enzymatic treatment of $\beta$-LG under high pressure may exhibit reduced antigenicity, IgE binding, or both (Bonomi et al., 2003; Fritsché, 2003; Peñas et al., 2006).

Previous studies in our laboratory have investigated the peptides released by the application of high pressure and proteolysis with trypsin and chymotrypsin on $\beta$-LG (Chicón et al., 2006a,b). In contrast with these enzymes, the use of pepsin allows the evaluation of not only a different enzyme but also an acidic environment that causes structural changes on $\beta$-LG, becoming a highly stable monomer, and reduces cross-linking due to SH/SS exchange. The objective of this research was to identify the peptides released by pepsin on $\beta$-LG, during or after the application of high pressure, and to evaluate their antigenicity and $\mathrm{IgE}$ binding. The aim was to obtain a better insight into the behavior of $\beta$ LG under pressure and to estimate the usefulness of this process to produce hypoallergenic hydrolysates.

\section{MATERIALS AND METHODS}

\section{Treatments with Pepsin at Atmospheric and High Pressure}

$\beta$-Lactoglobulin A was isolated from the $\mathrm{pH} 4.6$ soluble fraction of a milk sample obtained from a homozygote cow, as described by Ebeler et al. (1990). Proteolysis was conducted with pepsin (EC 3.4.23.1) from porcine stomach mucosa (570 units/mg; Sigma Chemicals Co., St. Louis, MO). A 2.0-mL solution containing native $\beta$-LG A (5.0 mg) and pepsin $(0.25 \mathrm{mg})$ in $50 \mathrm{~m} M$ citrate buffer, $\mathrm{pH} 2.5$, was immediately incubated at $37^{\circ} \mathrm{C}$, at atmospheric pressure in a water bath for up to $48 \mathrm{~h}$, or under high pressure (i.e., 100, 200, 300, and 400 $\mathrm{MPa}$ ) for up to $120 \mathrm{~min}$, using a 900-HP apparatus (Eurotherm Automation, Lyon, France). For the hydrolysis experiments conducted at atmospheric pressure on the prepressurized protein, $\beta$-LG A was dissolved in $50 \mathrm{~m} M$ Tris- $\mathrm{HCl}$ buffer, $\mathrm{pH} 6.8$, and treated at 100, 200, 300 , or $400 \mathrm{MPa}$ and 22 to $25^{\circ} \mathrm{C}$ for $20 \mathrm{~min}$. Immediately after depressurization, the $\mathrm{pH}$ was adjusted to 2.5 with $1 N \mathrm{HCl}$ and pepsin (1:20) was added to the pressurized substrate, incubating in a water bath at $37^{\circ} \mathrm{C}$ for 5 to $60 \mathrm{~min}$. The enzyme reaction was stopped in all cases by raising the $\mathrm{pH}$ to $6.5-7$ by the addition of $2 \mathrm{~N} \mathrm{NaOH}$. Samples were immediately freeze-dried and kept at refrigeration temperatures until used. Duplicate samples were prepared and analyzed.

\section{SDS-PAGE}

Lyophilized hydrolysates were reconstituted in 10 $\mathrm{m} M$ Tris- $\mathrm{HCl}$, $\mathrm{pH}$ 8.0, containing $2.5 \%$ SDS, $10 \mathrm{~m} M$ EDTA, and 5.0\% $\beta$-mercaptoethanol and immediately heated at $100^{\circ} \mathrm{C}$ for $10 \mathrm{~min}$. The SDS-PAGE was done on a PhastSystem Electrophoresis apparatus, using precast high-density gels and PhastGel SDS buffer strips (Amersham Biosciences, Uppsala, Sweden), following the electrophoretic and silver staining conditions of the manufacturer.

\section{HPLC-MS/MS}

The reversed-phase (RP)-HPLC with UV detection, online with electrospray ionization and quadrupole ion trap instrument (ESI-MS/MS) analyses, were performed as previously described by Chicón et al. (2006a), using an Agilent 1100 Series HPLC equipment (Agilent Technologies, Waldbronn, Germany) with a Hi-Pore Reversed Phase RP-318 Column $(250 \times 4 \mathrm{~mm}$ i.d., BioRad Laboratories, Hercules, CA) and an Esquire 3000 mass spectrometer (Bruker Daltonik, Bremen, Germany). Using Data Analyze (version 3.0, Bruker Daltonik), the $\mathrm{m} / z$ spectral data were processed and transformed to spectra representing mass values. Biotools (version 2.1, Bruker Daltonik) was used to process the MS(n) spectra and to perform peptide sequencing. To aid the identification of disulfide linked fragments the hydrolysates were also analyzed by RP-HPLC-MS/MS after a reducing step using dithiothreitol, at a final concentration of $70 \mathrm{mM}$ and $\mathrm{pH} 7.0$, for $1 \mathrm{~h}$ at $37^{\circ} \mathrm{C}$.

To compare the peptide content in different eluting fractions of the chromatographic separation, a quantitative estimation of the area under defined limits of the HPLC chromatograms was done by manually setting the integration limits and automatically integrating the areas using Agilent Chemstation software (revision A.05.01, Agilent Technologies). The calculated chromatogram areas in the different fractions corresponded to F1 (12 to $23 \mathrm{~min}$ ), F2 (23 to $30 \mathrm{~min}$ ), F3 (30 to $36 \mathrm{~min}$ ), F4 (36 to $50 \mathrm{~min}$ ), and the $\beta$-LG peak. The total peptide fraction was calculated as $\mathrm{PF}=\mathrm{F} 1+\mathrm{F} 2+\mathrm{F} 3+\mathrm{F} 4$, and the total content of protein and peptides was Tot $=\mathrm{PF}$ $+\beta-\mathrm{LG}=\mathrm{F} 1+\mathrm{F} 2+\mathrm{F} 3+\mathrm{F} 4+\beta-\mathrm{LG}$.

\section{Antigenicity and IgE Binding}

Residual antigenicity (i.e., IgG binding) of the samples was evaluated by indirect ELISA. High binding polystyrene microtiter plates (Corning, Cambridge, MA) were used as solid support. Single wells were coated with $50 \mu \mathrm{L}$ of antigen $(2.5 \mu \mathrm{g} / \mathrm{mL}$ of $\beta$-LG or $\beta$ LG hydrolysates) in $0.01 M$ PBS solution, $\mathrm{pH} 7.4$, and incubated overnight at $6^{\circ} \mathrm{C}$. Plates were washed with 
PBS containing $0.05 \%$ Tween 20. Plates were blocked with PBS containing 2.5\% Tween 20 for $1 \mathrm{~h}$ at room temperature and incubated with $50 \mu \mathrm{L} /$ well of horseradish peroxidase-conjugated rabbit antibovine $\beta$-LG IgG (Bethyl Laboratories, Montgomery, TX) diluted 1:20,000 in PBS. A solution of o-phenylene-diamine dihydrochloride (DakoCytomation) containing $\mathrm{H}_{2} \mathrm{O}_{2}$ was added following the instructions of the manufacturer. Plates were incubated for $30 \mathrm{~min}$ at room temperature in the dark, and the reaction was stopped by adding 50 $\mu \mathrm{L} /$ well of $0.5 \mathrm{M} \mathrm{H}_{2} \mathrm{SO}_{4}$. Optical densities were read at $492 \mathrm{~nm}$ on an automated ELISA plate reader Multiskan Ascent (Labsystems, Helsinki, Finland).

The IgE binding was evaluated by indirect ELISA, using patients' sera. Individual serum samples from children with proven allergy to bovine milk proteins were collected with written consent at the Hospital Gregorio Marañón (Madrid, Spain) fulfilling ethical requirements. All patients showed specific IgE antibodies toward milk proteins, particularly $\beta$-LG, as determined by the FEIA-CAP System (Pharmacia Diagnostics, Uppsala, Sweden). The pooled serum of 5 healthy nonallergic people was used as negative control. The assay was performed similarly as above but incubating with 50 $\mu \mathrm{L} /$ well of serum diluted 1:20 in PBS containing $0.05 \%$ Tween 20 overnight at $6^{\circ} \mathrm{C}$. After blocking, $50 \mu \mathrm{L} /$ well horseradish peroxidase-conjugated rabbit anti-human IgE (DakoCytomation, Glostrup, Denmark) was added at a 1:1,000 dilution in PBS-Tween, and plates were incubated for $1 \mathrm{~h}$ at room temperature. A signal amplification system (ELAST ELISA amplification system, PerkinElmer Life Sciences, Waltham, MA) was used following the instructions of the manufacturer. The reaction was revealed with $o$-phenylene-diamine dihydrochloride as described above.

The ELISA determinations were carried out in triplicate and measurements averaged. A blank without antigen (PBS) and a positive control containing intact $\beta$ LG were included in each plate.

\section{RESULTS AND DISCUSSION}

\section{Effect of High Pressure on the Susceptibility of $\beta$-LG to Pepsin Hydrolysis}

The extent of hydrolysis of $\beta$-LG by pepsin under the different pressure conditions was estimated by SDSPAGE as shown in Figure 1. In addition, the RP-HPLCUV chromatograms, illustrated in Figure 2, allowed for the evaluation of the evolution of the peptide pattern. No major qualitative differences were found in the hydrolysates, but the amounts of the different peptides varied depending on the conditions of enzyme treatment (Figure $2 \mathrm{a}, \mathrm{c}$, and e). The total peptide content was calculated as the area of the peptide fraction $(\mathbf{P F})$
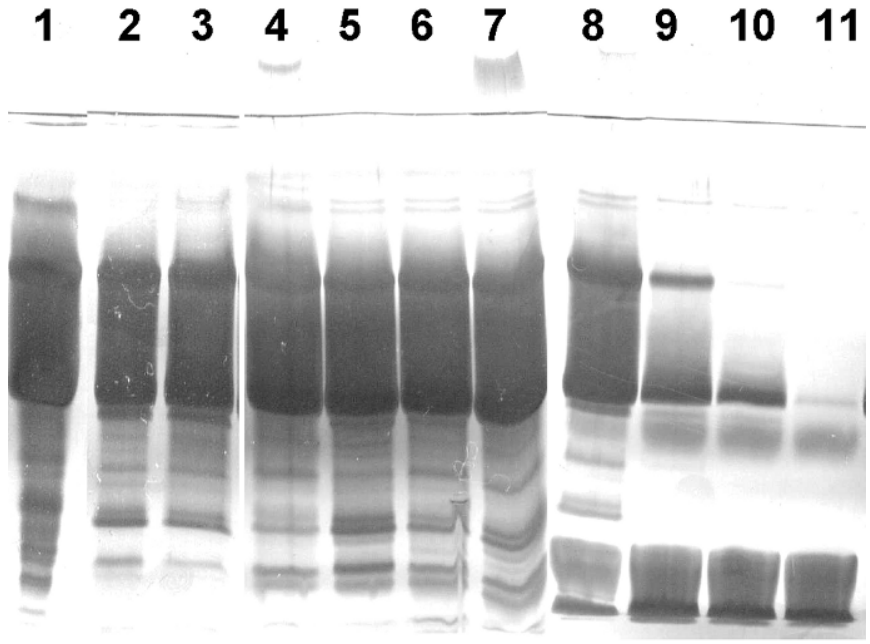

Figure 1. The SDS-PAGE of hydrolysates of $\beta$-LG obtained with pepsin under different pressure conditions. Lane 1: control native $\beta$ LG; lanes 2 and 3: hydrolysates obtained at atmospheric pressure on native $\beta$-LG for 8 and $24 \mathrm{~h}$, respectively. Lanes $4,5,6$, and 7 : hydrolysates obtained at atmospheric pressure for $1 \mathrm{~h}$ on prepressurized $\beta$-LG $(100,200,300$, and $400 \mathrm{MPa}$, respectively, for $20 \mathrm{~min})$; lanes $8,9,10$, and 11: hydrolysates obtained under high pressure, at $100,200,300$, and $400 \mathrm{MPa}$, respectively, for $20 \mathrm{~min}$ on native $\beta$-LG.

relative to the area of all peaks (Tot) that included, when present, the peak of intact $\beta$-LG (PF/Tot in Table 1). In addition, we quantified the peak areas of 4 peptide groups corresponding to different regions of the chromatogram (F1, F2, F3, and F4) relative to the total peptide area $(\mathrm{PF})$ that included all peptide groups (Table 1).

The results obtained from SDS-PAGE (Figure 1, lanes 2 to 3 ) and the total peptide content estimated by HPLC-UV (Figure 2a, Table 1) showed that native $\beta$-LG was weakly susceptible to pepsin at atmospheric pressure, in agreement with previous reports (Reddy et al., 1988; Dalgalarrondo et al., 1995; Otte et al., 1997). The peptide fraction slowly increased with time, but complete hydrolysis was not achieved even after 48 $\mathrm{h}$ of incubation with the enzyme. Proteolysis time caused a progressive decrease in the higher retention time fraction, F4, whereas $\mathrm{F} 1$ and $\mathrm{F} 2$ increased, indicating that F4 contained mainly intermediate fragments that were proteolysed further to smaller peptides.

Treatment of $\beta$-LG at neutral $\mathrm{pH}$ and pressures $\geq 200$ $\mathrm{MPa}$ promoted its subsequent proteolysis by pepsin at atmospheric pressure, although a considerable amount of the protein was still present in its full length after $60 \mathrm{~min}$ of enzymatic treatment (Figure 1, lanes 4 to 7, Figure 2c, Table 1). Proteolysis was more efficient because the pressure used was higher. This supports previous findings showing that pressure-induced struc- 


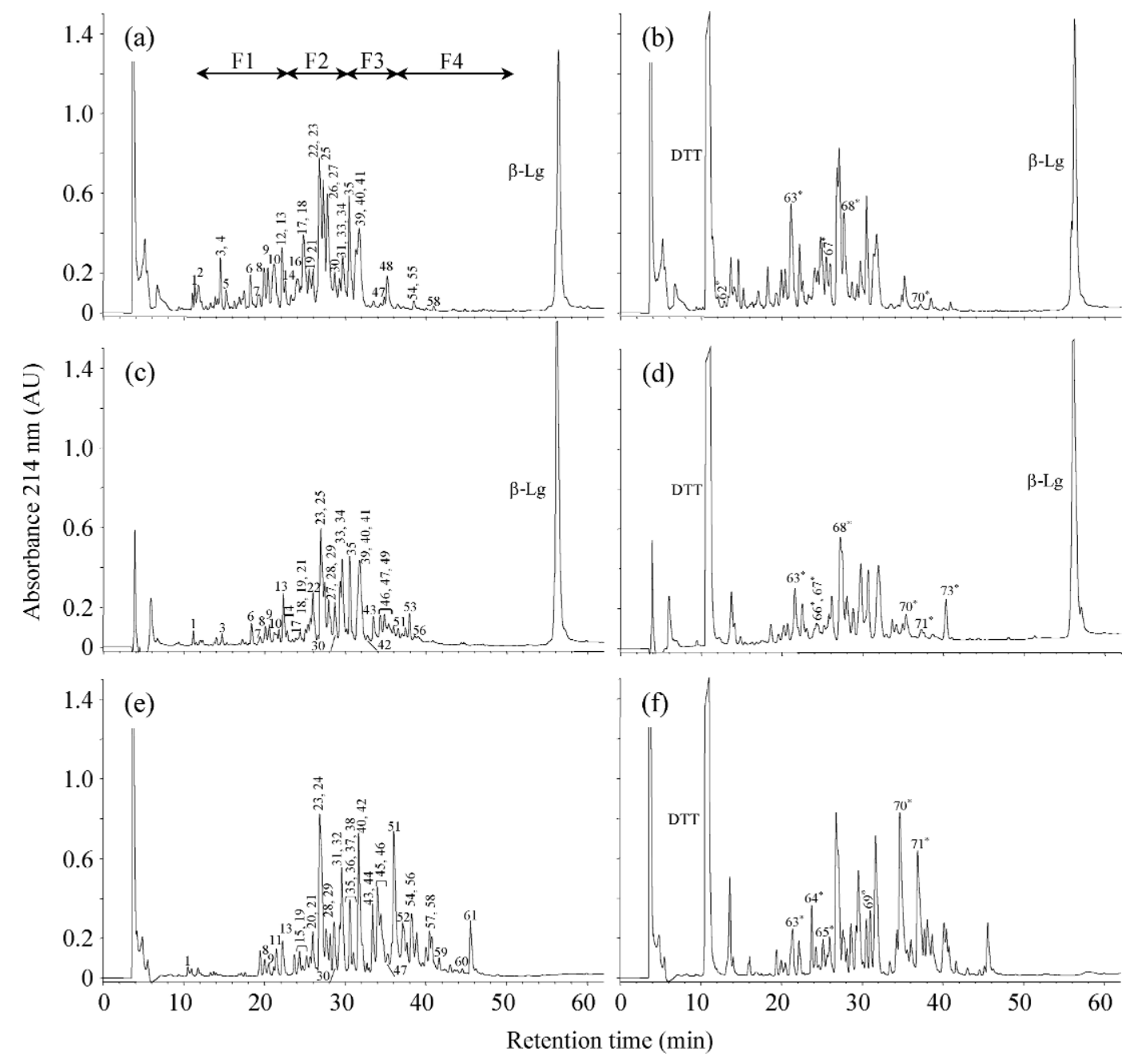

Figure 2. HPLC-UV chromatograms of $\beta$-LG hydrolysates obtained with pepsin in the absence (a, c, e) and presence of dithiothreitol (DTT; b, d, f). Native $\beta$-LG hydrolyzed at atmospheric pressure for $48 \mathrm{~h}$ (a, b); prepressurized $\beta$-LG (400 MPa, 20 min) hydrolyzed at atmospheric pressure for $60 \mathrm{~min}$ (c, d); native $\beta$-LG hydrolyzed under $400 \mathrm{MPa}$ for $5 \mathrm{~min}$ (e, f). Peak numbers correspond to the peptides identified by MS/MS (Table 2). F1, F2, F3, and F4 correspond to the fractions in Table 1.

tural changes on $\beta$-LG facilitate pepsin action (Dufour et al., 1995; Stapelfeldt et al., 1996; Belloque et al., 2007). The total peptide fraction in the hydrolysates obtained at atmospheric pressure on $\beta$-LG increased with prepressurization from 200 to $400 \mathrm{MPa}$ (see PF/ Tot in Table 1), but extending the hydrolysis time from 5 to 60 min did not make much difference in the overall amount of peptides released. This indicates that little proteolysis of the intact protein occurred after the first 5 min, probably due to the capacity of the protein to recover its structure after decompression (Ikeuchi et al., 2001; Belloque et al., 2007). However, the incubation time of the prepressurized substrate with pepsin changed the relative proportion of the different peptide fractions, with F4 decreasing markedly from 5 to 60 min of incubation with the enzyme. This suggests that the intermediate peptides contained in $\mathrm{F} 4$ were better substrates for the enzyme action than the whole protein.

Under high pressure, the protein was hydrolyzed very efficiently. As compared with atmospheric pressure, enzyme treatments at 200 to $400 \mathrm{MPa}$ dramatically increased the proteolysis rate of $\beta$-LG. The peptide fraction ( $\mathrm{PF} / \mathrm{Tot})$ increased with pressure and with incubation time, and no intact $\beta$-LG was found after 5 min at $400 \mathrm{MPa}$ (Table 1). Previous studies performed under similar conditions of pressure and time but with different enzymes working at neutral $\mathrm{pH}$, such as trypsin and chymotrypsin, showed that proteolysis was enhanced at $100 \mathrm{MPa}$ (Chicón et al., 2006a,b). The observation that proteolysis was not promoted at $100 \mathrm{MPa}$ under the present conditions can be attributed to the 
Table 1. Relative area of peptide fractions (from HPLC chromatograms) and antigenicty (from ELISA with a commercial anti- $\beta$-LG antibody), obtained from pepsin hydrolysis of $\beta$-LG A subjected to different treatments with high pressure ${ }^{1}$

\begin{tabular}{|c|c|c|c|c|c|c|c|c|}
\hline \multirow{3}{*}{ 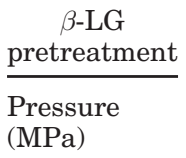 } & \multicolumn{2}{|c|}{ Enzyme hydrolysis } & \multirow{2}{*}{\multicolumn{5}{|c|}{ Fraction relative area }} & \multirow{3}{*}{$\begin{array}{c}\text { Antigenicity } \\
\text { IgG } \\
\text { binding }\end{array}$} \\
\hline & \multirow{2}{*}{$\begin{array}{l}\text { Pressure } \\
(\mathrm{MPa})\end{array}$} & \multirow{2}{*}{$\begin{array}{l}\text { Time } \\
(\mathrm{min})\end{array}$} & & & & & & \\
\hline & & & PF/Tot & $\mathrm{FI} / \mathrm{PF}$ & $\mathrm{F} 2 / \mathrm{PF}$ & $\mathrm{F} 3 / \mathrm{PF}$ & $\mathrm{F} 4 / \mathrm{PF}$ & \\
\hline None & 0.1 & 0 & - & - & - & - & - & 3.55 \\
\hline None & 0.1 & 5 & 0.10 & 0.14 & 0.17 & 0.11 & 0.58 & 3.34 \\
\hline None & 0.1 & 60 & 0.17 & 0.14 & 0.34 & 0.20 & 0.32 & 3.74 \\
\hline None & 0.1 & 480 & 0.33 & 0.17 & 0.47 & 0.17 & 0.20 & 3.07 \\
\hline None & 0.1 & 1,440 & 0.51 & 0.21 & 0.56 & 0.18 & 0.05 & 2.68 \\
\hline None & 0.1 & 2,880 & 0.76 & 0.24 & 0.57 & 0.12 & 0.07 & 2.27 \\
\hline $100^{2}$ & 0.1 & 5 & 0.05 & 0.16 & 0.11 & 0.17 & 0.55 & 4.02 \\
\hline $100^{2}$ & 0.1 & 30 & 0.14 & 0.11 & 0.29 & 0.13 & 0.47 & 3.96 \\
\hline $100^{2}$ & 0.1 & 60 & 0.13 & 0.13 & 0.36 & 0.17 & 0.33 & 3.97 \\
\hline $200^{2}$ & 0.1 & 5 & 0.28 & 0.16 & 0.37 & 0.14 & 0.33 & 3.76 \\
\hline $200^{2}$ & 0.1 & 30 & 0.27 & 0.17 & 0.43 & 0.16 & 0.24 & 3.96 \\
\hline $200^{2}$ & 0.1 & 60 & 0.27 & 0.17 & 0.45 & 0.16 & 0.22 & 3.79 \\
\hline $300^{2}$ & 0.1 & 5 & 0.47 & 0.07 & 0.32 & 0.12 & 0.50 & 3.81 \\
\hline $300^{2}$ & 0.1 & 30 & 0.47 & 0.11 & 0.45 & 0.19 & 0.25 & 3.35 \\
\hline $300^{2}$ & 0.1 & 60 & 0.49 & 0.17 & 0.48 & 0.18 & 0.17 & 3.34 \\
\hline $400^{2}$ & 0.1 & 5 & 0.57 & 0.06 & 0.41 & 0.14 & 0.39 & 3.26 \\
\hline $400^{2}$ & 0.1 & 30 & 0.62 & 0.11 & 0.46 & 0.18 & 0.26 & 3.60 \\
\hline $400^{2}$ & 0.1 & 60 & 0.62 & 0.14 & 0.49 & 0.19 & 0.19 & 3.60 \\
\hline None & 100 & 5 & 0.22 & 0.09 & 0.30 & 0.18 & 0.42 & 3.53 \\
\hline None & 100 & 10 & 0.24 & 0.10 & 0.35 & 0.18 & 0.37 & 3.98 \\
\hline None & 100 & 20 & 0.34 & 0.10 & 0.38 & 0.15 & 0.37 & 4.17 \\
\hline None & 200 & 5 & 0.76 & 0.05 & 0.32 & 0.14 & 0.48 & 3.13 \\
\hline None & 200 & 10 & 0.87 & 0.06 & 0.34 & 0.13 & 0.47 & 2.26 \\
\hline None & 200 & 20 & 0.94 & 0.08 & 0.39 & 0.16 & 0.38 & 1.11 \\
\hline None & 300 & 5 & 0.97 & 0.07 & 0.34 & 0.19 & 0.40 & 1.10 \\
\hline None & 300 & 10 & 0.98 & 0.08 & 0.35 & 0.16 & 0.41 & 0.82 \\
\hline None & 300 & 20 & 0.99 & 0.08 & 0.38 & 0.19 & 0.34 & 0.43 \\
\hline None & 400 & 5 & $1.00^{3}$ & 0.06 & 0.30 & 0.17 & 0.47 & 0.42 \\
\hline None & 400 & 10 & $1.00^{3}$ & 0.08 & 0.35 & 0.19 & 0.38 & 0.32 \\
\hline None & 400 & 20 & $1.00^{3}$ & 0.09 & 0.39 & 0.24 & 0.28 & 0.10 \\
\hline None & 400 & 60 & $1.00^{3}$ & 0.14 & 0.47 & 0.26 & 0.13 & 0.06 \\
\hline None & 400 & 120 & $1.00^{3}$ & 0.17 & 0.51 & 0.22 & 0.10 & 0.02 \\
\hline
\end{tabular}

${ }^{1}$ The areas of fractions correspond to $\mathrm{F} 1$ (12 to $23 \mathrm{~min}$ ), F2 (23 to $30 \mathrm{~min}$ ), F3 (30 to $36 \mathrm{~min}$ ), and F4 (36 to $50 \mathrm{~min})$, $\mathrm{PF}(\mathrm{F} 1+\mathrm{F} 2+\mathrm{F} 3+\mathrm{F} 4)$, Tot $(\mathrm{F} 1+\mathrm{F} 2+\mathrm{F} 3+\mathrm{F} 4+\beta-\mathrm{LG})$. See Figure 2 for visualization of the fractions. Antigenicity values in absorbance $(492 \mathrm{~nm})$ units.

${ }^{2}$ Prepressurization at given pressure for $20 \mathrm{~min}$ at 22 to $25^{\circ} \mathrm{C}$.

${ }^{3}$ Complete hydrolysis.

structural stability of the protein at acid $\mathrm{pH}$ (Reddy et al., 1988; Dufour et al., 1995; Stapelfeldt et al., 1996; Belloque et al., 2007). Between 200 and $400 \mathrm{MPa}$ there were no clear differences in the relative proportions of the peptide fractions, but at each pressure level, F4 decreased and F1/F2 increased with the incubation time.

The comparison between the hydrolysates obtained under atmospheric pressure and under high pressure with a similar level of $\beta$-LG degradation (PF/Tot) revealed that proteolysis under high pressure led to higher peptide content in fraction $\mathrm{F} 4$, whereas the peptide contents in F1 and F2 were considerably lower. We have previously proposed that proteolysis of $\beta$-LG under high pressure at neutral $\mathrm{pH}$ follows a progressive mechanism that involves the rapid disappearance of the pro- tein to yield large peptides, which are then hydrolyzed more slowly to release smaller peptides (Chicón et al., $2006 \mathrm{a}, \mathrm{b})$. This is supported by the present findings at acid $\mathrm{pH}$ : intact $\beta$-LG was hydrolyzed rapidly under high pressure, leading to the accumulation of intermediate peptides during the early stages of proteolysis that were further degraded on extending incubation with the enzyme. In contrast, at atmospheric pressure, the persistent presence of the intact protein after $48 \mathrm{~h}$ of hydrolysis and the low amount of intermediate peptides indicate that the proteolysis on the protein was difficult and slow, but once the resulting intermediate peptides were released, they were further hydrolyzed to smaller fragments with more ease.

It has to be mentioned that no SS-bonded aggregates of $\beta$-LG were found when the protein was subjected to 
high pressure in the absence of enzyme (results not shown), in agreement with the low reactivity of the thiol group at acid $\mathrm{pH}$.

\section{Peptides Released by Pepsin on $\beta-L G$ as Influenced by Previous or Simultaneous High-Pressure Treatments}

Table 2 shows the sequences of the peptides identified by RP-HPLC-MS/MS in the hydrolysates of $\beta$-LG. Most fragments derived from the cleavage of the Phe, Tyr, Trp, and Leu residues, in agreement with the specificity of the enzyme. Other cleaved bonds involved Ile, Glu, Asp, and Gln residues.

In general terms, most peaks were found in all the samples, but in very different amounts (Figure 2a, c, and e). Similarly, Dufour et al. (1995) reported that hydrolysis of $\beta$-LG by pepsin shows only pressure-induced rate increases that are not followed by any pressure-induced cleavage specificity. In the hydrolysates obtained at atmospheric pressure on the prepressurized protein and, especially in those obtained under high pressure, particularly at $400 \mathrm{MPa}$, the late eluting HPLC peptides were prominent (Figure $2 \mathrm{a}, \mathrm{c}$, and e). Some fragments appeared to be the consequence of primary cuts on the protein, whereas others were the result of further proteolysis of the primary fragments. All primary fragments were formed more easily when the protein was treated under high pressure and, thus, they accumulated at short hydrolysis times. When proteolysis was performed at $400 \mathrm{MPa}$ and long times (e.g., $120 \mathrm{~min}$ ), proteolysis evolved so that the late-eluting peptides, such as Val ${ }^{123}-\mathrm{His}^{146}(58), \mathrm{Val}^{123}-\mathrm{Leu}^{149}(61)$, $\mathrm{Phe}^{82}-\mathrm{Leu}^{95}$ (57), Lys ${ }^{83}-\mathrm{Leu}^{95}$ (51), and $\mathrm{Ile}^{29}-\mathrm{Val}^{41}(54)$ disappeared, giving rise to smaller peptides with shorter retention times (results not shown).

In the hydrolysates obtained under high pressure, the peptide Val ${ }^{123}$-Leu ${ }^{149}(61)$ was present in high amounts, suggesting that pressurization promoted a primary cleavage at $\mathrm{Leu}^{122}-\mathrm{Val}^{123}$ and $\mathrm{Leu}^{149}-\mathrm{Ser}^{150}$ bonds. The shorter sequence $\mathrm{Val}^{123}-\mathrm{His}^{146}(58)$ was also prominent, indicating that the longer fragment, once released, was easily proteolyzed to the smaller one. Some peptides resulting from proteolysis of both fragments, such as $(52,59,60,43,8$, and 28), were evidenced. The SS bonded peptide $\mathrm{Leu}^{58}-\mathrm{Val}^{81}(\mathrm{SS}) \mathrm{Ser}^{150}-\mathrm{Ile}^{162}$ (44) was very important, as well as its separate peptides, Leu ${ }^{58}$ $\mathrm{Val}^{81}(69)$ and $\mathrm{Ser}^{150}-\mathrm{Ile}^{162}$ (71), and other related ones [i.e., $\left.\mathrm{Leu}^{58}-\mathrm{Phe}^{82}(70)\right]$. This indicated that, in addition to $\mathrm{Leu}^{149}-\mathrm{Ser}^{150}$, the bonds $\mathrm{Leu}^{57}-\mathrm{Leu}^{58}$ and $\mathrm{Val}^{81}$ $\mathrm{Phe}^{82}-\mathrm{Lys}^{83}$ were very susceptible to proteolysis under high pressure. In addition, the simultaneous presence of Ser ${ }^{150}-\mathrm{Ile}^{162}$ (71) and the products resulting from its cleavage through the bond $\mathrm{Leu}^{156}-\mathrm{Glu}^{157}$ (35, 63, and
46) indicated that the latter is rapidly cleaved once the longer fragment is released of the protein. Other important fragments were $\mathrm{Lys}^{83}-\mathrm{Leu}^{95}$ (51) and $\mathrm{Phe}^{82}$ $\mathrm{Leu}^{95}$ (57), and shorter fragments within these sequences such as $(38,38,15$, and 13), but their signals were not as high. This confirmed the higher susceptibility of $\mathrm{Val}^{81}-\mathrm{Phe}^{82}-\mathrm{Lys}^{83}$ bonds and indicated that $\mathrm{Leu}^{95}-\mathrm{Glu}^{96}$ cleavage was also favored by high pressure. It was found that $\mathrm{Leu}^{95}-\mathrm{Leu}^{104}(45)$ was only present in high pressure treated samples and Asp ${ }^{96}-\mathrm{Phe}^{105}$ (56) was considerably high, indicating that $\mathrm{Val}^{94}$ Leu $^{95}-$ Asp $^{96}$ and Leu ${ }^{104}-\mathrm{Phe}^{105}-\mathrm{Cys}^{106}$ cleavages were favored by high pressure. The peptide $\mathrm{Ile}^{29}-\mathrm{Val}^{41}(54)$ was also very high in the pressure-treated sample, as compared with the samples hydrolyzed at atmospheric pressure. This indicated that the bonds $\mathrm{Val}^{41}-\mathrm{Tyr}^{42}$ $\mathrm{Val}^{43}$ and $\mathrm{Asp}^{28}-\mathrm{Ile}^{29}$ were particularly susceptible to cleavage under high pressure. Its proteolysis products (21 and 30) were slightly enhanced. Other fragments that showed the favored cleavage of the bond $\mathrm{Val}^{41}$ $\mathrm{Tyr}^{42}$ were $\mathrm{Tyr}^{42}-\mathrm{Leu}^{54}$ (31) and $\mathrm{Tyr}^{42}-\mathrm{Glu}^{55}$ (29). Their presence, besides, indicated that bonds $\mathrm{Leu}^{54}-\mathrm{Glu}^{55}$ $\mathrm{Ile}^{56}$ were favorably broken under high pressure. Fragments coming from these 2 latter peptides (24 and 11) were increased in the samples hydrolyzed under high pressure. It has to be noted that no SS-bonded peptides resulting from SH/SS exchange reactions were found, in agreement with the absence of pressure-induced SSbonded protein aggregates (see above).

It can be inferred from the rapid formation of all primary fragments, which sequences were distributed throughout the whole protein (Figure 3), that $\mathrm{Asp}^{28}$ / $\mathrm{Ile}^{29}, \mathrm{Tyr}^{42}, \mathrm{Leu}^{54}, \mathrm{Leu}^{57} / \mathrm{Leu}^{58}, \mathrm{Phe}^{82}, \mathrm{Leu}^{95}, \mathrm{Leu}^{104} /$ $\mathrm{Phe}^{105}$, Leu ${ }^{122}$, Leu ${ }^{149}$ were target residues that became more available to pepsin by the application of high pressure. Some residues $\left(\mathrm{Leu}^{54}, \mathrm{Phe}^{82}\right.$, Leu ${ }^{95}, \mathrm{Phe}^{105}$, and Leu ${ }^{122}$ ) were not accessible to the enzyme in the native protein. The residues $\mathrm{Leu}^{54}$ and $\mathrm{Phe}^{82}$ are closely located within the protein, as well as $\mathrm{Leu}^{95}, \mathrm{Phe}^{105}$, and $\mathrm{Leu}^{122}$, a fact that is probably related to their similar behavior. Residues Leu ${ }^{95}$, Phe ${ }^{105}$, and Leu ${ }^{122}$ lie in the FGH strands, a robust region of the protein (Belloque et al., 2000). The exposure to the solvent of $\mathrm{Leu}^{104}$ and $\mathrm{Phe}^{105}$ is difficult at acid $\mathrm{pH}$, but they become increasingly exposed as the pressure increases from 200 to 400 MPa (Belloque et al., 2007). The residues $\mathrm{Arg}^{40}$ and $\mathrm{Arg}^{148}$, as well as Tyr ${ }^{42}$ and Leu ${ }^{149}$ are favorably cleaved by trypsin and chymotrypsin, respectively, under high pressure, a fact that has been mainly attributed to the dissociation of the dimer (Chicón et al., 2006a,b). However, at acid $\mathrm{pH}, \beta$-LG is already a monomer at atmospheric pressure, and thus, the proteolysis enhancement of these residues must be due to other conformational changes. Because $\mathrm{Leu}^{149}$ is located in the I strand, 
Table 2. Peptide sequences arising from the hydrolysis of $\beta$-LG A with pepsin under different pressure conditions, as determined by reversed-phase HPLC-MS ${ }^{1}$

\begin{tabular}{|c|c|c|c|}
\hline Peak & $m / z^{2}$ & Protein fragment & Sequence \\
\hline 1 & 494.2 & $24-28$ & (A)MAASD(1) \\
\hline 2 & 861.4 & $109-116$ & (E)NSAEPEQS(L) \\
\hline 3 & 561.3 & $85-89$ & (I)DALNE(V) \\
\hline 4 & 539.3 & $42-45$ & (V)YVEE(L) \\
\hline 5 & 645.5 & $137-142$ & (F)DKALKA(L) \\
\hline 6 & 497.4 & $143-146$ & (A)LPMH(I) \\
\hline 7 & 877.6 & $2-9$ & (L)IVTQTMKG(L) \\
\hline 8 & 930.5 & $123-130$ & (L)VRTPEVDD(E) \\
\hline 9 & $1,059.5$ & $123-131$ & (L)VRTPEVDDE(A) \\
\hline 10 & 974.4 & $109-117$ & (E)NSAEPEQSL(A) \\
\hline 11 & 856.5 & $47-54$ & (L)KPTPEGDL(E) \\
\hline 12 & 920.6 & $135-142$ & (E)KFDKALKA(L) \\
\hline 13 & 802.6 & $83-89$ & (F)KIDALNE(N) \\
\hline 14 & $1,049.6$ & $134-142$ & (L)EKFDKALKA(L) \\
\hline 15 & $1,143.5$ & $83-92$ & (F)KIDALNENKV \\
\hline 16 & 661.9 & $14-19$ & (Q)KVAGTW(Y) \\
\hline 17 & 809.6 & $140-146$ & (A)LKALPMH(I) \\
\hline 18 & 969.6 & $46-54$ & (E)LKPTPEGDL(E) \\
\hline 19 & 770.5 & $35-41$ & (A)QSAPLRV(Y) \\
\hline 20 & 990.5 & $1-9$ & LIVTQTMKG(L) \\
\hline 21 & 956.5 & $33-41$ & (L)DAQSAPLRV(Y) \\
\hline 22 & $1,105.5$ & $2-11$ & (L)IVTQTMKGLD(I) \\
\hline 23 & 902.6 & $12-19$ & (D)IQKVAGTW(Y) \\
\hline 24 & $1,098.6$ & $45-54$ & (E)ELKPTPEGDL(E) \\
\hline 25 & $1,233.6$ & $132-142$ & (E)ALEKFDKALKA(L) \\
\hline 26 & $1,337.0(2)$ & 58-73(SS)157-162 & \\
\hline 27 & $1,326.6$ & $43-54$ & (Y)VEELKPTPEGDL(E) \\
\hline 28 & $1,243.5$ & $123-133$ & (L)VRTPEVDDEAL(E) \\
\hline 29 & $1,618.6$ & $42-55$ & (V)YVEELKPTPEGDLE(I) \\
\hline 30 & $1,069.6$ & $32-41$ & (L)LDAQSAPLRV(Y) \\
\hline 31 & $1,489.5$ & $42-54$ & (V)YVEELKPTPEGDL(E) \\
\hline 32 & $1,232.6$ & $42-42$ & (L)LDAQSAPLRVY(V) \\
\hline 33 & $1,527.6$ & $134-146$ & (L)LPEKFDKALKALPMH(I) \\
\hline 34 & 827.6 & 99-104 & (D)YKKYLL(F) \\
\hline 35 & 806.5 & $150-156$ & (L)SFNPTQL(E) \\
\hline 36 & $1,180.6(2)$ & $58-81(\mathrm{SS}) 157-162$ & \\
\hline 37 & $1,290.6$ & $82-92$ & (V)FKIDALNENKV(L) \\
\hline 38 & $1,355.7$ & $83-94$ & (F)KIDALNENKVLV(L) \\
\hline 39 & 903.6 & $75-82$ & (E)KTKIPAVF(K) \\
\hline 40 & $1,158.6$ & 96-104 & (L)DTDYKKYLL(F) \\
\hline 41 & $1,032.6$ & $74-82$ & (A)EKTKIPAVF(K) \\
\hline 42 & $1,218.7$ & $1-11$ & LIVTQTMKGLD(I) \\
\hline 43 & $1,711.8$ & $132-146$ & (E)ALEKFDKALKALPMH(I) \\
\hline 44 & $1,443.4(3)$ & 58-81(SS)150-162 & \\
\hline 45 & $1,271.6$ & $95-104$ & (V)LDTDYKKYLL(F) \\
\hline 46 & $1,844.1(2)$ & 58-82(SS)157-162 & \\
\hline 47 & $1,130.5$ & $10-19$ & (G)LDIQKVAGTW(Y) \\
\hline 48 & 879.6 & $143-149$ & (A)LPMHIRL(S) \\
\hline 49 & $1,370.6$ & 94-104 & (L)VLDTDYKKYLL(F) \\
\hline 50 & $1,840.7$ & $131-146$ & (D)EALEKFDKALKALPMH(I) \\
\hline 51 & $1,468.7$ & $83-95$ & (F)KIDALNENKVLVL(E) \\
\hline 52 & $1,909.9$ & $134-149$ & (L)EKFDKALKALPMHIRL(S) \\
\hline 53 & $1,393.3(2)$ & 105-122(SS)157-162 & \\
\hline 54 & $1,382.7$ & $29-41$ & (D)ISLLDAQSAPLRV(Y) \\
\hline 55 & $1,483.7$ & 93-104 & (V)LVLDTDYKKYLL(F) \\
\hline 56 & $1,305.6$ & $96-105$ & (L)DTDYKKYLLF(C) \\
\hline 57 & $1,615.8$ & $82-95$ & (V)FKIDALNENKVLVL(E) \\
\hline 58 & $1,376.5(2)$ & $123-146$ & (L)VRTPEVDDEALEKFDKALKALPMH(I) \\
\hline 59 & $1,112.1(2)$ & $131-149$ & (D)EALEKFDKALKALPMHIRL(S) \\
\hline 60 & $1,169.5(2)$ & $130-149$ & (D)DEALEKFDKALKALPMHIRL(S) \\
\hline 61 & $1,567.7(2)$ & $123-149$ & (L)VRTPEVDDEALEKFDKALKALPMHIRL(S) \\
\hline $62^{*}$ & 609.2 & $62-66$ & (W)ENDEC(A) \\
\hline $63^{*}$ & 758.5 & $157-162$ & (L)EEQCHI \\
\hline $64^{*}$ & $1,371.4$ & $105-116$ & (L)FCMENSAEPEQS(L) \\
\hline $65^{*}$ & 871.5 & $156-162$ & (L)LEEQCHI \\
\hline $66^{*}$ & $1,164.5$ & $58-66$ & (L)LQKWENDEC(A) \\
\hline
\end{tabular}


Table 2 (Continued). Peptide sequences arising from the hydrolysis of $\beta$-LG A with pepsin under different pressure conditions, as determined by RP-HPLC-MS ${ }^{1}$

\begin{tabular}{llll}
\hline Peak & $m / z^{2}$ & Protein fragment & \multicolumn{1}{c}{ Sequence } \\
\hline $67^{*}$ & 565.3 & $118-122$ & (L)VCQCL(V) \\
$68^{*}$ & $1,916.7$ & $58-73$ & (L)LQKWENDECAQKKIIA(E) \\
$69^{*}$ & $1,392.2(2)$ & $58-81$ & (L)LQKWENDECAQKKIIAEKTKIPAV(F) \\
$70^{*}$ & $1,465.7(2)$ & $58-82$ & (L)LQKWENDECAQKKIIAEKTKIPAVF(K) \\
$71^{*}$ & $1,545.5$ & $150-162$ & (L)SFNPTQLEEQCHI \\
$72^{*}$ & $1,578.9$ & $56-82$ & (E)ILLQKWENDECAQKKIIAEKTKIPAVF(K) \\
$73^{*}$ & $2,030.3$ & $105-122$ & (L)FCMENSAEPEQSLVCQCL(V) \\
\hline
\end{tabular}

${ }^{1}$ Peak numbers correspond to numbers in HPLC chromatograms (Figure 2). *Peptides marked with an asterisk were found in dithiothreitol-treated samples. Sequence amino acids between brackets represent flanking residues.

${ }^{2}$ Molecular ion selected for MS/MS charge.

where it interacts in an antiparallel manner with the A strand, it is possible that it becomes more exposed through the dissociation of both strands under high pressure.

The restricted proteolysis of $\beta$-LG by pepsin at atmospheric pressure makes it difficult to identify the proteolysis products of this enzyme (Otte et al., 1997). Some authors have identified the peptides formed during pepsinolysis of native bovine (Chobert et al., 1995; Dalgalarrondo et al., 1995) and ovine $\beta$-LG (El-Zahar et al., 2005), esterified $\beta$-LG (Chobert et al., 1995), or $\beta$-LG in ethanol solution (Dalgalarrondo et al., 1995). Only one report has been found that describes 11 peptides released on proteolysis $\beta$-LG with pepsin under high pressure (Dufour et al., 1995). Comparing these fragments with those found in the present study, it can be inferred that Dufour and coworkers described mainly secondary products. It has to be pointed out that some secondary peptides are formed rapidly under high-pres- sure conditions probably because the primary fragments are more readily available. Actually, many secondary peptides appeared simultaneously with primary peptides at short proteolysis times under high-pressure conditions. On the contrary, other secondary products, such as those derived from cleavage at $\mathrm{Leu}^{143}$ and $\mathrm{Glu}^{74}$, required longer times to appear, what indicated that these residues were more difficult to cleave even under high pressure. Finally, some sites $\left(\mathrm{Leu}^{39}, \mathrm{Leu}^{87}, \mathrm{Leu}^{102}\right.$, and Leu ${ }^{103}$ ) were evidenced as very tough targets for pepsin, as they were not attacked by the enzyme. The $\mathrm{Leu}^{39}$ is preceded by a proline residue, which is known to inhibit pepsin action. The reason why Leu ${ }^{87}, \mathrm{Leu}^{102}$, and Leu ${ }^{103}$ were also difficult targets is less clear. However, it can be speculated that some of the primary fragments released, $\mathrm{Phe}^{83}-\mathrm{Leu}^{95}$ and $\mathrm{Val}^{96}-\mathrm{Leu}^{105}$, that have a hairpin conformation in the native structure (Figure 3) could maintain some secondary structure that would interfere with the enzyme activity.
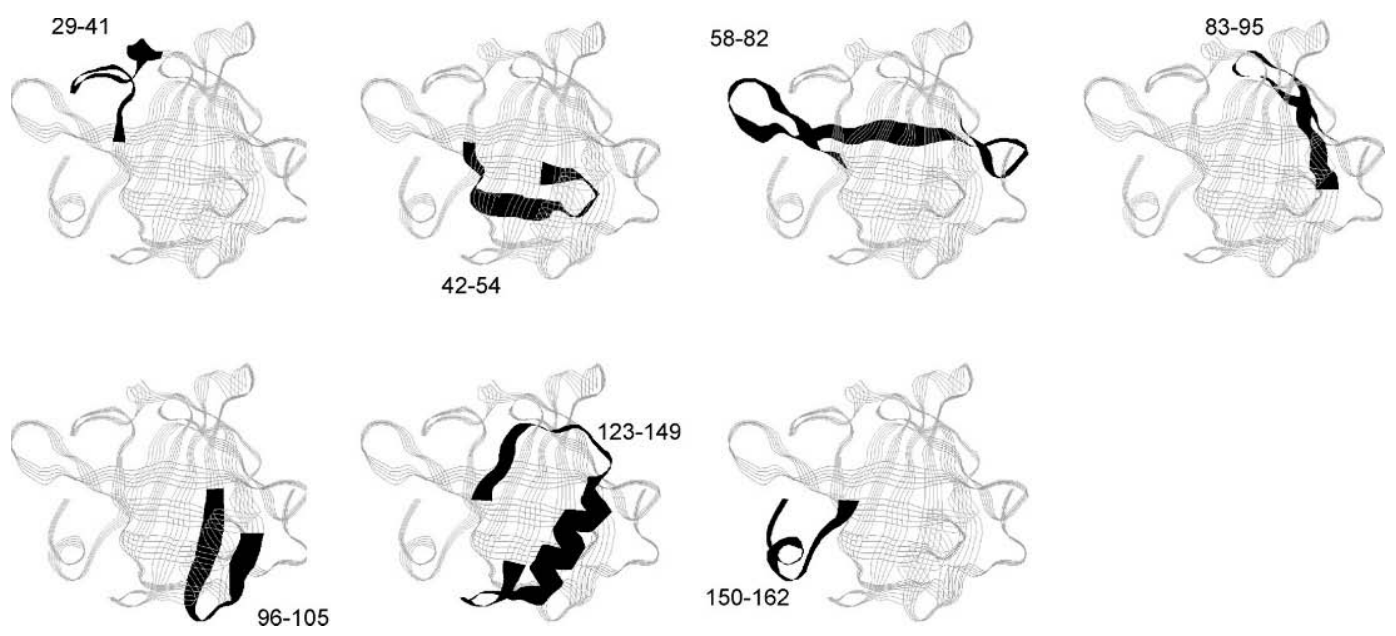

Figure 3. View of the 3D structure of $\beta$-LG and some primary fragments favorably cleaved by proteolysis with pepsin under high pressure. Model built with RasWin Molecular Graphics, version 2.6, using the coordinates from the Protein Data Bank, PDB ID: 1BEB (Brownlow et al., 1997). 
Table 3. Specific binding to IgE of allergic patients' sera of selected hydrolysates obtained by incubation of $\beta$-LG with pepsin at $37^{\circ} \mathrm{C}$, different pressures and different times, in absorbance units, as measured by indirect ELISA $^{1}$

\begin{tabular}{|c|c|c|c|c|c|c|c|c|c|}
\hline \multirow[b]{2}{*}{ Sample } & \multicolumn{2}{|c|}{ Pepsin hydrolysis } & \multicolumn{7}{|c|}{$\begin{array}{c}\text { Serum IgE binding } \\
\text { (ELISA response, Abs. } 492 \mathrm{~nm} \text { ) }\end{array}$} \\
\hline & $\begin{array}{l}\text { Pressure } \\
(\mathrm{MPa})\end{array}$ & Time & $\mathrm{S} 1$ & $\mathrm{~S} 2$ & S3 & S4 & S5 & S6 & S7 \\
\hline Control (native $\beta$-LG) & - & - & 2.76 & 2.48 & 2.43 & 3.5 & 1.09 & 2.5 & 2.16 \\
\hline Hydrolysates at atmospheric pressure & 0.1 & $24 \mathrm{~h}$ & 2.85 & 2.67 & - & - & - & - & - \\
\hline (contain intact $\beta$-LG) & 0.1 & $48 \mathrm{~h}$ & 2.76 & 2.79 & - & - & - & - & - \\
\hline Hydrolysates at high pressure & 400 & $5 \mathrm{~min}$ & 1.92 & 1.17 & 1.78 & - & - & - & - \\
\hline (no intact $\beta$-LG present) & 400 & $10 \mathrm{~min}$ & 1.53 & 1.18 & 1.06 & - & - & - & - \\
\hline & 400 & $20 \mathrm{~min}$ & 0.82 & 0.70 & 1.02 & 0.30 & $<0.1$ & $<0.1$ & $<0.1$ \\
\hline & 400 & $60 \mathrm{~min}$ & 0.24 & 0.55 & 0.50 & 0.25 & $<0.1$ & $<0.1$ & $<0.1$ \\
\hline & 400 & $120 \mathrm{~min}$ & 0.22 & 0.20 & $<0.1$ & $<0.1$ & $<0.1$ & $<0.1$ & $<0.1$ \\
\hline$\beta$-LG-specific serum titer $(\mathrm{kU} / \mathrm{L})$ & & & 55.7 & 68.6 & 31.9 & 42.3 & 5.6 & 20.1 & 29.4 \\
\hline
\end{tabular}

${ }^{1}$ Individual sera labeled as S1 to S7. Absorbance values of $<0.1$ mean very low response. The protein/ peptide content, corresponding to $2.5 \mu \mathrm{g} / \mathrm{mL}$, was the same in all samples.

\section{Changes in Antigenicity and IgE Binding of $\beta$-LG Hydrolysates}

The antigenic response of the different $\beta$-LG hydrolysates toward a commercial anti- $\beta$-LG antibody (Table 1) was high in all samples containing intact protein. These included all samples hydrolyzed at atmospheric pressure, either native or prepressurized. Only a slight reduction was observed in the native samples incubated with the enzyme for a long time (i.e., 24 and $48 \mathrm{~h}$ ) at atmospheric pressure. This is consistent with the progressive removal of the intact protein revealed in the $\mathrm{PF} / \mathrm{Tot}$ values. Some prepressurized samples (e.g., at $400 \mathrm{MPa}$ ) showed no significant reduction of IgG binding while containing a similar or higher peptide amount $(\mathrm{PF} / \mathrm{Tot})$ than the native samples hydrolyzed for 24 to $48 \mathrm{~h}$. This could be explained by the accumulation of the peptides in the $\mathrm{F} 4$ fraction of the prepressurized hydrolysates, which probably carry a significant antigenic load. A clear decrease in antigenicity was evidenced when the protein was hydrolyzed under pressures $\geq 200 \mathrm{MPa}$, and the reduction was more intense as the incubation pressure and time increased. The extensive reduction of intact $\beta$-LG $(\mathrm{PF} / \mathrm{Tot} \geq 0.90)$ caused a considerable decrease in antigenicity. However, the complete removal of the protein $(\mathrm{PF} / \mathrm{Tot}=$ 1.00) did not completely cancel the IgG response, which progressively decreased with time like the $\mathrm{F} 4$ fraction.

Some hydrolysates were selected for testing their binding capacity to serum $\operatorname{IgE}$ from allergic patients (Table 3). No reduction in the response was found when $\beta$-LG was proteolyzed at atmospheric pressure, but the response decreased on incubation with the enzyme under high pressure. A considerably reduction in the IgE binding was already found in the hydrolysates obtained at $400 \mathrm{MPa}$ for short periods, 5 to $10 \mathrm{~min}$, and an increase in the incubation time with the enzyme led to a progressive decrease of IgE binding. The serum titer greatly influenced the reactivity against IgE. Sera with lower titers (S5, S6, S7) showed no IgE binding for samples obtained at $400 \mathrm{MPa}$ for $20 \mathrm{~min}$, whereas sera with higher titers (S1 and S2) showed some reactivity against the hydrolysates obtained at incubation times as long as $120 \mathrm{~min}$.

The observation that in the absence of protein there were still positive antigenic and $\mathrm{IgE}$ binding responses, particularly against the commercial antibody and the sera with higher titers, suggested again that the intermediate peptides, such as those in F4, preferentially formed at the initial stages of hydrolysis under high pressure, contained immunoreactive epitopes. As illustrated in Table 4, strong candidates for such reactivity are Leu ${ }^{95}-\mathrm{Leu}^{104}(45)$ and $\mathrm{Asp}^{96}-\mathrm{Phe}^{105}$ (56), which are similar to fragments 95-113 and 97-108 that have shown positive reactions with $100 \%$ of the sera from allergic patients (Ball et al., 1994; Heinzmann et al., 1999). In addition, Selo et al. (1999) found that a similar sequence, $92-100$, still reacted with sera from $52 \%$ of the patients. The fragment $\operatorname{Ser}^{150}-\mathrm{Ile}^{162}(71)$ would also be potentially allergenic because it is very similar to 149-162, which has reacted against sera belonging to $89 \%$ of the allergic patients (Selo et al., 1999). The $\mathrm{Tyr}^{42}-\mathrm{Leu}^{54}$ (31) is included in the sequence 41-60 that has been found to react with sera from $92 \%$ of the allergic patients (Selo et al., 1999). Selo et al. (1999) have also found a positive reaction in $72 \%$ of the allergic patients toward the fragment 25-40, similar to $\mathrm{Ile}^{29}$ $\mathrm{Val}^{41}$ (54). Heinzmann et al. (1999) found the sequence 124-135 reactive toward IgE only for some patients. The peptides $\mathrm{Val}^{123}-\mathrm{His}^{146}(58)$ and $\mathrm{Val}^{123}-\mathrm{Leu}^{149}(61)$ contain it, as well as some shorter fragments (8 and 9). In addition, sequences similar to $\mathrm{Phe}^{82}-\mathrm{Leu}^{95}$ (57) or Lys $^{83}-$ Leu $^{95}$ (51), particularly 84-91 and 85-96, have 
Table 4. Primary peptides (released from the protein) and secondary peptides (released from primary peptides) found in $\beta$-LG hydrolysates, as deduced from their order of appearance as hydrolysis progressed, and related peptides described as allergenic in the literature ${ }^{1}$

\begin{tabular}{|c|c|c|}
\hline Primary peptides & Secondary peptides & $\begin{array}{c}\text { Peptides } \\
\text { described as } \\
\text { allergenic }{ }^{2,3,4}\end{array}$ \\
\hline $29-41(54)$ & $\begin{array}{ll}33-41 & (21) \\
32-41 & (30)\end{array}$ & $25-40^{2}$ \\
\hline $42-54(31)$ & $42-45(4)$ & $41-60^{2}$ \\
\hline $42-55(29)$ & $\begin{array}{l}46-54(18) \\
47-54(11)\end{array}$ & \\
\hline 58-81 (69) & $58-66(66)$ & \\
\hline $58-82(70)$ & $58-73(68)$ & \\
\hline 58-82(SS)157-162 (46) & $\begin{array}{l}74-82(41) \\
75-82 \quad(39)\end{array}$ & \\
\hline $82-95(57)$ & 82-92 (37) & $84-91^{3}$ \\
\hline $83-95(51)$ & $\begin{array}{ll}83-94 & (38) \\
83-92 & (15) \\
83-89 & (13) \\
85-89 & (3)\end{array}$ & $85-96^{2}$ \\
\hline $\begin{array}{l}95-104(45) \\
96-105(56)\end{array}$ & $\mathrm{ND}^{5}$ & $\begin{array}{l}95-113^{3} \\
97-108^{4} \\
92-100^{2}\end{array}$ \\
\hline $123-149(61)$ & $\begin{array}{ll}123-146 & (58) \\
123-130 & (8) \\
123-131 & (9) \\
123-133 & (28) \\
130-149 & (60) \\
131-149 & (59) \\
134-149 & (52) \\
134-146 & (33) \\
134-142 & (14) \\
143-146 & (6)\end{array}$ & $124-135^{3}$ \\
\hline $150-162(71)$ & $\begin{array}{l}150-156(35) \\
157-162(63) \\
58-82(\mathrm{SS}) 157-162(46)\end{array}$ & $149-162^{2}$ \\
\hline
\end{tabular}

${ }^{1}$ Numbers in parentheses correspond to the peptide numbers in Figure 2 and Table 2.

${ }^{2}$ Selo et al. (1999).

${ }^{3}$ Ball et al. (1994).

${ }^{4}$ Heinzmann et al. (1999).

${ }^{5}$ Not detected.

reacted positively with sera from 40 and $44 \%$ of the allergic patients, respectively (Ball et al., 1994; Selo et al., 1999).

In conclusion, hydrolysis of $\beta$-LG with pepsin at acid $\mathrm{pH}$ was greatly accelerated by the application of high pressures during the enzymatic treatment. A progressive proteolysis mechanism was evidenced, and considering previous results, it is concluded that this mechanism occurs at atmospheric and high pressure as well as at neutral and acid pH. This mechanism allowed obtaining hydrolysates with different immunochemical properties by selecting the incubation time with the enzyme. At $400 \mathrm{MPa}$ all the intact protein was removed by pepsin in minutes scale, reducing simultaneously the antigenicity and serum $\operatorname{IgE}$ binding properties. However, for obtaining hydrolysates with very low antibody binding capacity, it was necessary to remove the intermediate peptides, which required hours of incubation with the enzyme under high pressure. This opens the possibility of obtaining hypoallergenic hydrolysates of $\beta$-LG, minimizing simultaneously the formation of new peptides cross-linked by disulphide bonds.

\section{ACKNOWLEDGMENTS}

This work has been supported by projects AGL-200403322 (Ministerio de Educación y Ciencia, Spain) and S-0505/AGR/0153 (Comunidad Autónoma de Madrid, Spain).

\section{REFERENCES}

Ball, G., M. J. Shelton, B. J. Walsh, D. Hill, C. S. Hosking, and M. E. H. Howden. 1994. A major continuous epitope of bovine $\beta$ lactoglobulin recognized by human IgE binding. Clin. Exp. Allergy 24:758-764.

Belloque, J., R. Chicón, and R. López-Fandiño. 2007. Unfolding and refolding of $\beta$-lactoglobulin subjected to high hydrostatic pressure at different $\mathrm{pH}$ values and temperatures and its influence on proteolysis. J. Agric. Food Chem. 55:5282-5288.

Belloque, J., R. López-Fandiño, and G. M. Smith. 2000. A 1H-NMR study on the effects of high pressure on the structure of $\beta$-lactoglobulin. J. Agric. Food Chem. 48:3906-3912.

Bonomi, F., A. Fiocchi, H. Frøkiær, A. Gaiaschi, S. Iametti, C. Poiesi, P. Rasmussen, P. Restain, and P. Rovere. 2003. Reduction of immunoreactivity of bovine $\beta$-lactoglobulin upon combined physical and proteolytic treatment. J. Dairy Res. 70:51-59.

Brownlow, S., J. H. Morais Cabral, R. Cooper, D. R. Flower, S. J. Yewdall, I. Polikarpov, A. C. North, and L. Sawyer. 1997. Bovine beta-lactoglobulin at 1.8 A resolution-Still an enigmatic lipocalin. Structure 15:481-495.

Chicón, R., J. Belloque, I. Recio, and R. López-Fandiño. 2006a. Influence of high hydrostatic pressure on the proteolysis pattern of $\beta$ lactoglobulin A treated with trypsin. J. Dairy Res. 73:121-128.

Chicón, R., R. López-Fandiño, A. Quirós, and J. Belloque. 2006b. Changes in chymotrypsin hydrolysis of $\beta$-lactoglobulin A induced by high hydrostatic pressure. J. Agric. Food Chem. 54:2333-2341.

Chobert, J. M., L. Briand, V. Grinberg, and T. Haertlé. 1995. Impact of esterification on the folding and the susceptibility to peptic proteolysis of $\beta$-lactoglobulin. Biochim. Biophys. Acta 1248:170-176.

Dalgalarrondo, M., E. Dufour, J. M. Chobert, C. Bertrand-Harb, and T. Haertlé. 1995. Proteolysis of $\beta$-casein by pepsin in ethanolic media. Int. Dairy J. 5:1-14.

Dufour, E., G. Hervé, and T. Haertlé. 1995. Hydrolysis of $\beta$-lactoglobulin by thermolysin and pepsin under high hydrostatic pressure. Biopolymers 35:475-483.

Ebeler, S. E., L. G. Phillips, and J. E. Kinsella. 1990. Purification of $\beta$-lactoglobulin: Isolation of genetic variants and influence of purification method on secondary structure. Milchwissenschaft 45:694-698.

El-Zahar, K., M. Sitohy, Y. Choiset, F. Métro, T. Haertlé, and J. M. Chobert. 2005. Peptic hydrolysis of ovine $\beta$-lactoglobulin and $\beta$ lactalbumin. Exceptional susceptibility of native ovine $\beta$-lactoglobulin to pepsinolysis. Int. Dairy J. 15:17-27.

Fritsché, R. 2003. Role for technology in dairy allergy. Aust. J. Dairy Technol. 58:89-91.

Guo, M. R., P. F. Fox, A. Flynn, and P. S. Kindstedt. 1995. Susceptibility of $\beta$-lactoglobulin and sodium caseinate to proteolysis by pepsin and trypsin. J. Dairy Sci. 78:2336-2344.

Heinzmann, A., S. Blattmann, P. Spuergin, J. Forster, and K. A. Deichmann. 1999. The recognition pattern of sequential B cell epitopes of $\beta$-lactoglobulin does not vary with the clinical manifestations of cow's milk allergy. Int. Arch. Allergy Immunol. 120:280-286. 
Host, A., and S. Halken. 2004. Hypoallergenic formulas-When, to whom and how long: After more than 15 years we know the right indication. Allergy 59(Suppl. 78):45-52.

Iametti, S., P. Rasmussen, H. Frøkiær, P. Ferranti, F. Addeo, and F. Bonomi. 2002. Proteolysis of bovine $\beta$-lactoglobulin during thermal treatment in subdenaturing conditions highlights some structural features of the temperature-modified protein and yields fragments with low immunoreactivity. Eur. J. Biochem. 269:1362-1372

Ikeuchi, Y., K. Nakagawa, T. Endo, A. Suzuki, T. Hayashi, and T. Ito. 2001. Pressure-induced denaturation of monomer $\beta$-lactoglobulin is partially irreversible: Comparison of monomer form (highly acidic $\mathrm{pH}$ ) with dimer form (neutral $\mathrm{pH}$ ). J. Agric. Food Chem. 49:4052-4059.

Knudsen, J. C., J. Otte, K. Olsen, and L. H. Skibsted. 2002. Effect of high hydrostatic pressure on the conformation of $\beta$-lactoglobulin A as assessed by proteolytic peptide profiling. Int. Dairy J. 12:791-803

Maynard, F., A. Weingand, J. Hau, and R. Jost. 1998. Effect of high pressure treatment on the tryptic hydrolysis of bovine $\beta$-lactoglobulin AB. Int. Dairy J. 8:125-133.

Otte, J., M. Zakora, K. B. Qvist, C. E. Olsen, and V. Barkholt. 1997. Hydrolysis of bovine $\beta$-lactoglobulin by various proteases and identification of selected peptides. Int. Dairy J. 7:835-848.

Peñas, E., G. Préstamo, M. L. Baeza, M. I. Martínez-Molero, and R. Gómez. 2006. Effect of enzymatic treatments on the hydrolysis and immunoreactivity of dairy whey proteins. Int. Dairy J. 16:831-839.

Ragona, L., F. Fogolari, M. Catalano, R. Ugolini, L. Zetta, and H. Molinari. 2003. EF loop conformational change triggers ligand binding in $\beta$-lactoglobulins. J. Biol. Chem. 278:38840-38846.

Reddy, I. M., N. K. Kella, and J. E. Kinsella. 1988. Structural and conformational basis of the resistance of $\beta$-lactoglobulin to peptic and chymotryptic digestion. J. Agric. Food Chem. 36:737-741.

Selo, I., G. Clement, H. Bernard, J. M. Chatel, C. Cremion, G. Peltre, and J. M. Wal. 1999. Allergy to bovine $\beta$-lactoglobulin. Specificity of human IgE to tryptic peptides. Clin. Exp. Allergy 29:10551063.

Stapelfeldt, H., P. H. Petersen, K. R. Kristiansen, K. B. Qvist, and L. H. Skibsted. 1996. Effect of high hydrostatic pressure on the enzymatic hydrolysis of $\beta$-lactoglobulin B by trypsin, thermolysin and pepsin. J. Dairy Res. 63:111-118.

Townend, R., L. Weinberger, and S. N. Timasheff. 1960. Molecular interactions in $\beta$-lactoglobulin. IV. The dissociation of $\beta$-lactoglobulin below pH 3.5. J. Am. Chem. Soc. 82:3175-3179.

Uhrinova, S., M. H. Smith, G. B. Jameson, D. Uhrin, L. Sawyer, and P. N. Barlow. 2000. Structural changes accompanying pHinduced dissociation of the beta-lactoglobulin dimer. Biochemistry 39:3565-3574.

Wal, J. M. 2001. Structure and function of milk allergens. Allergy 56(Suppl. 67):35-38. 